\title{
Use of peanut milk residue in the preparation of cookies
}

\section{T.L. Dharsenda AND M.N. DabH**}

Department of Processing and Food Engineering, College of Agricultural Engineering and Technology, Junagadh Agricultural Engineering, JUNAGADH (GUJARAT) INDIA

Email : mndabhi@jau.in

\section{SUMMARY :}

The aim of this study was to assess the effect of substitute peanut milk residue (PMR) flour in place of refined wheat flour (RWF)on the physico-chemical and sensory properties of cookies. Five variations were formed such as C-I (RWF:PMR=90:10), C-II (RWF:PMR=80:20), CIII(RWF:PMR=70:30), C-IV (RWF:PMR=60:40),C-V(RWF:PMR=50:50). The statistical analysis showed that only the parameters of moisture content and carbohydrates were significantly influenced by the amount of peanut milk residue. Through sensory analysis of colour, flavour, texture, taste and appearance, it was found that the best percentage of peanut milk residue substitution was 50 per cent. Though the sensory score for control (100\% RWF) was higher but all the treatments were statistically non-significant. This proposes the use of peanut milk residue may be considered a source of protein as they contain $26 \mathrm{~g} / 100 \mathrm{~g}$ protein.

KEY WORDS : Peanut milk residue, Cookies, Protein

How to cite this paper : Dharsenda, T.L. and Dabhi, M.N. (2016). Use of peanut milk residue in the preparation of cookies. Internat. J. Proc. \& Post Harvest Technol., 7 (1) : 21-28. DOI: 10.15740/HAS/ IJPPHT/7.1/21-28 